\title{
Adapting to climate change: a perspective from evolutionary physiology
}

\author{
Steven L. Chown ${ }^{1, *}$, Ary A. Hoffmann ${ }^{2}$, Torsten N. Kristensen ${ }^{3,4}$, \\ Michael J. Angilletta Jr. ${ }^{5}$, Nils Chr. Stenseth ${ }^{6}$, Cino Pertoldi ${ }^{3,7}$ \\ ${ }^{1}$ Centre for Invasion Biology, Department of Botany and Zoology, Stellenbosch University, Private Bag X1, Matieland 7602, \\ South Africa \\ ${ }^{2}$ The University of Melbourne, Bio21 Institute, 30 Flemington Road, Parkville, Victoria 3052, Australia \\ ${ }^{3}$ Department of Biological Sciences, Ecology and Genetics, Aarhus University, Ny Munkegade, Building 1540, \\ DK-8000 Århus C, Denmark \\ ${ }^{4}$ Department of Genetics and Biotechnology, Aarhus University, Blichers Allé 20, DK-8830 Tjele, Denmark \\ ${ }^{5}$ School of Life Sciences Arizona, State University, Tempe, Arizona 85287, USA \\ ${ }^{6}$ Centre for Ecological and Evolutionary Synthesis, Department of Biology, PO Box 1066 Blindern, 0316 Oslo, Norway \\ ${ }^{7}$ Mammal Research Institute, Polish Academy of Sciences, Waszkiewicza 1c, 17-230 Białowieża, Poland
}

\begin{abstract}
Much attention has been given to forecasting the likely effects of ongoing climate change on biodiversity. A large and often contentious literature has developed about how changes in species' ranges should be modelled and how additional biological mechanisms might be incorporated to improve their utility. Nonetheless, 2 areas stand out as relatively underappreciated: the importance of understanding a species' physiological capacities when forecasting its response to climate change, and the likely influence that capacities for genetic change across generations and changes in plastic responses, or the lack thereof, will have on a species' response. Although perhaps not as well developed as correlative approaches to understanding species responses to change, mechanistic approaches are advancing rapidly. In this review, we explore several of the key messages emerging from the mechanistic approach, embodied in evolutionary physiology, to understanding and forecasting species responses to climate change.
\end{abstract}

KEYWORDS: Physiological ecology $\cdot$ Macrophysiology $\cdot$ Phenotypic plasticity $\cdot$ Demography Adaptation $\cdot$ Selection

Resale or republication not permitted without written consent of the publisher

\section{INTRODUCTION}

In October 2009, the International Energy Agency (IEA) announced a major opportunity to mitigate climate change presented by the downturn in carbon emissions resulting from the global financial crisis. Their forecast estimated an emissions reduction of $3 \%$, bringing a future target of $450 \mathrm{ppm} \mathrm{CO}_{2}$ apparently within reasonable reach (IEA 2009). Whilst the IEA report is optimistic about the political feasibility of a 450 ppm target (compare this with the IPCC Special Report on Emissions Scenarios; IPCC 2000), and achieving such a target would certainly reduce the extent of ongoing climate change, given the radiative forcing of $\mathrm{CO}_{2}$ as a greenhouse gas (Archer \& Rahmstorf 2010), the present course of human activities still commits the globe to substantial changes in climate. Indeed, even if radiative forcing remained at the level experienced in 2000, warming and other changes in climate would continue. Independent assessments also indicate that the trajectory of emissions has exceeded even the highest forecasts made by the IPCC (IPCC 2007). Thus the planet is now committed to anthropogenic climate change. Moreover, new evaluations suggest that dangerous environmental impacts will require smaller degrees of warming than previously thought (Smith et al. 2009). 
Biologists no longer doubt that biological systems have already responded to the current global anthropogenic changes in climate. Many studies have demonstrated substantial shifts in the geographic ranges and phenologies of species from a broad array of taxa, indicating a coherent fingerprint of climate change (e.g. Walther et al. 2002, Parmesan \& Yohe 2003, Genner et al. 2004, Nussey et al. 2005, Both et al. 2006, Møller et al. 2006, Parmesan 2006, Pörtner \& Knust 2007, Lenoir et al. 2008, le Roux \& McGeoch 2008, Chen et al. 2009, Steltzer \& Post 2009). Given the substantial evidence of shifting ranges and phenologies, and of substantial range shifts in the past (Dynesius \& Jansson 2000, Davis \& Shaw 2001), much attention has also been given to forecasting the likely effects of ongoing climate change on species and ecosystems from these perspectives (e.g. Midgley et al. 2003, Thomas et al. 2004, Thuiller et al. 2006, Kearney et al. 2008). A large body of often contentious literature has developed about how changes in species' ranges should be modelled and how additional biological mechanisms might be incorporated to improve their utility (e.g. Pearson \& Dawson 2003, Elith et al. 2006, Hijmans \& Graham 2006, Brooker et al. 2007, Soberón 2007, Sutherst et al. 2007, Beale et al. 2008, Jeschke \& Strayer 2008, Keith et al. 2008, Elith \& Graham 2009).

Nonetheless, 2 areas stand out as relatively underappreciated: the importance of understanding a species' physiological capacities when forecasting its response to climate change (reviewed by Helmuth et al. 2005, Kearney \& Porter 2009), and the likely influence that capacities for genetic change across generations and changes in plastic responses, or the lack thereof, will have on a species' response (Lande \& Shannon 1996, Stillman 2003, Bradshaw \& Holzapfel 2006, 2008, van Asch et al. 2007, Kearney et al. 2009a). In many ways, these 2 areas of research are inseparable. If evolutionary or plastic adjustments are impossible (or simply slower than the rate required to keep up with environmental change), the demographic effects of a mismatch between physiological capacities (in a multispecies context, see de Mazancourt et al. 2008) and environmental variation will lead to local extinction. Indeed, when the rate of environmental change is below ca. $10 \%$ of a phenotypic standard deviation per generation, mean time to extinction increases rapidly (Burger \& Lynch 1995). The degree of unpredictability of an environment can also make the presence of genetic variance disadvantageous (Lande \& Shannon 1996). Thus patterns of environmental noise will affect responses to environmental change (Stenseth et al. 2002, Tuljapurkar et al. 2003, Ranta et al. 2006, Pertoldi et al. 2008). If organisms can locate new areas that are better suited to their physiological capacities, a range shift might take place; however, if such sites are unavailable or inaccessible (Hill et al. 1999, Perry et al. 2005), the population is likely to go extinct. Consequently, understanding the extent to which current ranges set variation in physiological characteristicsand the extent to which such characteristics might change via either plasticity or evolution-form key elements of forecasting biological responses to global change (Chown \& Terblanche 2007, Pörtner \& Farrell 2008, Hoffmann 2010). Although perhaps not as well developed as correlative approaches, mechanistic approaches are advancing rapidly (e.g. Kearney \& Porter 2009). Here we explore several of the messages emerging from mechanistic modelling.

\section{PHYSIOLOGICAL TRAITS AND FUNDAMENTAL LIMITS}

Organisms posses a wide range of systems that maintain function, restrict damage or depress metabolism under extreme conditions (such as up-regulation of heat shock proteins; Feder \& Hofmann 1999, Sørensen et al. 2003). Understanding how and why these systems vary through space and time to ensure survival and reproduction lies at the very heart of evolutionary physiology (Prosser 1986, Hoffmann \& Parsons 1997, Mangum \& Hochachka 1998, Feder et al. 2000, Hochachka \& Somero 2002, Sørensen et al. 2003, Chown et al. 2004). Thus evolutionary physiology has particular significance in the context of climate change responses.

One concept in evolutionary physiology that has proven especially fruitful from both theoretical and empirical perspectives is that of the performance curve (Fig. 1). This concept has been applied in a variety of guises (e.g. Huey \& Stevenson 1979, Vannier 1994, Pörtner 2001), but in essence all performance curves represent the response of a physiological rate to a change in an environmental variable. Furthermore, one can consider how the form of this response might change under various circumstances (Levins 1968, Gilchrist 1995, Kingsolver \& Huey 1998, Davis et al. 2005). Performance curves also provide a point of departure for investigations of the biochemical and cellular mechanisms underlying variation in particular physiological functions (Pörtner 2001, 2002, de Jong \& van der Have 2008). Most commonly, the environmental variable of interest is temperature, but physiological and vital rates (e.g. reproduction, expected lifetime fecundity $\left[R_{o}\right]$, and maximum intrinsic rate of increase $\left.\left[r_{\max }\right]\right)$ also vary with other environmental variables (such as pH and humidity) (Chown \& Gaston 2008). These performance curves, and their spatial and temporal variation, provide a useful means of understanding how physiological variation can influence a spe- 


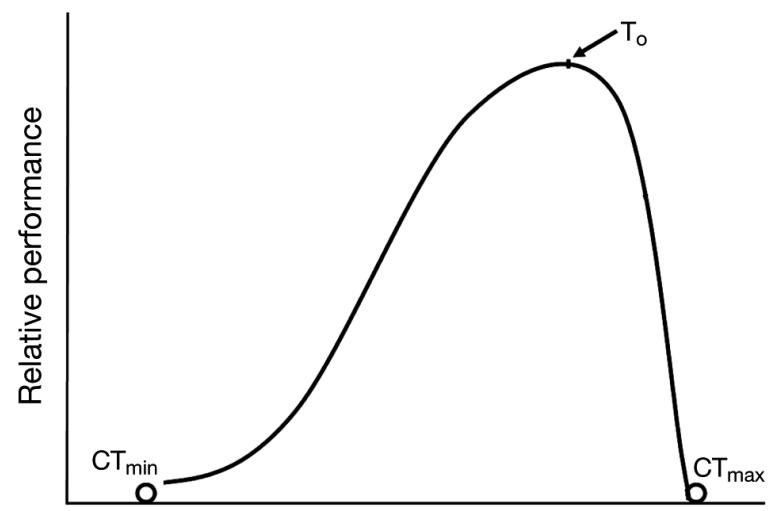

Body temperature

Fig. 1. A typical thermal performance curve. Parameters such as the optimal temperature $\left(\mathrm{T}_{\mathrm{o}}\right)$, critical thermal maximum $\left(\mathrm{CT}_{\max }\right)$ and critical thermal minimum $\left(\mathrm{CT}_{\min }\right)$ have a considerable influence on fitness (Angilletta 2009). Figure courtesy of S. Clusella-Trullas

cies' response to climate change (Buckley 2008). Such relationships also underlie physiologically based species distribution models (Crozier \& Dwyer 2006, Austin 2007, Buckley 2008, Kearney \& Porter 2009, Kearney et al. 2009a). Consequently, renewed attention has been given to the thermal sensitivity of performance and to thermal limits in general, as well as the application of these physiological measures in the laboratory to ecological problems in nature (e.g. Angilletta et al. 2002, 2006, Loeschcke \& Hoffmann 2007, Pörtner \& Knust 2007, Kristensen et al. 2008b, Chown et al. 2009, Kellermann et al. 2009).

A theoretical understanding of variation in the limits, breadth, optima and maxima of thermal performance curves is well developed. Perhaps one of the most notable conclusions of a recent review thereof (Angilletta 2009) is that empirical evidence has failed in many cases to support the predictions of current theory. This mismatch between theory and data might stem from ecological interactions among species, costs of resource acquisition and spatial structure of the environment - all of which have not been adequately captured by existing models (Davis et al. 1998, de Mazancourt et al. 2008, Angilletta 2009, Mitchell \& Angilletta 2009). The mismatch might also result from fundamental limits to some aspects of thermal performance curves. For example, whilst metabolic functions of metazoans have an upper thermal limit of ca. $47^{\circ} \mathrm{C}$ (Pörtner 2002), heat tolerance seems to have limited capacity for genetic and plastic responses (Gilchrist \& Huey 1999, Chown 2001, Mitchell \& Hoffmann 2010). Likewise, thermal specialists and generalists differ substantially in the extent to which physiological limits might evolve (Hoffmann et al. 2003a, Kellermann et al. 2009). Nonetheless, theory has clarified expectations for when and how physiological traits might significantly influence demographics, and thus geographical distributions and range limits (see e.g. Holt et al. 1997).

Biologists have empirically demonstrated that physiological traits can limit the distributions and ranges of species (reviewed in Hoffmann \& Blows 1994, Gaston 2003, 2009). Moreover, the fact that species richness depends strongly on temperature provides further support for this idea (see Allen et al. 2002, Clarke \& Gaston 2006, Wang et al. 2009). Nonetheless, many approaches to niche modelling assume implicitly (and sometimes incorrectly) that geographic distributions provide an adequate index of a species' environmental tolerance (e.g. Bonier et al. 2007). Not only may other factors be responsible for influencing species range limits and abundance structure, but the direction of causality may also sometimes be difficult to discern (Gaston 2003, 2009). Be that as it may, physiological traits play an important initial demographic role by influencing survival and reproduction under a given set of environmental conditions (Soberón 2007).

The significance of understanding such relationships between the phenotype and the environment has recently been highlighted by 2 studies (Deutsch et al. 2008, Huey et al. 2009). Both studies considered environmental temperatures and thermal optima in a spatially explicit context. These studies define: (1) the difference between the optimal temperature for physiological performance and the mean (or maximal) body temperature as the 'thermal safety margin', and (2) the difference between the critical thermal maximum $\left(\mathrm{CT}_{\max }\right)$ and the mean (or maximal) body temperature as the 'warming tolerance'. By analyzing latitudinal variation in the safety margin and the warming tolerance, these studies have shown that tropical ectotherms could be at considerably greater risk from environmental warming than their temperate counterparts.

Whether tropical ectotherms are actually at greater risk than temperate organisms from environmental warming is a more difficult question to answer than some biologists have acknowledged. From a climatic perspective, both current and forecasted changes in temperature may be accompanied by increased precipitation and cloud cover in many tropical regions (Trenberth \& Shea 2005, Meehl et al. 2007, Trenberth et al. 2007, Adler et al. 2008, Zhou et al. 2009), which could reduce thermal loads for ectotherms in these areas. By contrast, regions just outside the tropics not only are historically prone to the highest environmental temperatures (Bonan 2002), but also are likely to experience less precipitation and cloud cover in the future. Thus ectotherms at these latitudes, rather than those in the tropics, might be most at risk. A more recent and larger compilation of data suggests that this may well be the case for squamate reptiles (S. Clusella- 
Trullas et al. unpubl data). Moreover, this study also showed that variation in preferred body temperatures and critical thermal maxima are more strongly related to the variances of precipitation and temperature, respectively, than either is to the mean temperature. Thus changes in mean environmental temperatures might have played a smaller role in the evolution of performance curves than have changes in thermal extremes and their interactions with precipitation (and likely cloud cover). In a similar vein, tropical species of Drosophila from eastern Australia have relatively high upper thermal limits which are no closer to thermal extremes likely to be experienced by these species in the field than are those of a non-tropical group (J. Overgaard et al. unpubl. data).

These findings highlight the significance not only of mean values for influencing the evolution of performance curves, but also variance in the parameter of interest, extreme events, the predictability of both and the time scale over which they take place relative to the duration of various stages (Angilletta et al. 2006, Chown \& Terblanche 2007). Along with changes in average conditions, changes in daily and seasonal variation and in the frequency of extreme events are an integral part of current and forecast climate change (Katz \& Brown 1992, Easterling et al. 2000, Jentsch \& Beierkuhnlein 2008, Knapp et al. 2008). Thus understanding the likely responses of traits to these changes, and the demographic consequences of any response, is important for forecasting the impacts of change. Indeed, a limited range of examples has already demonstrated the considerable demographic and evolutionary significance of extreme events and combinations of events that increase physiological stress (Grant \& Grant 1993, Brown \& Brown 1998, Parmesan et al. 2000, Gutschick \& BassiriRad 2003, Helmuth et al. 2006, Jentsch et al. 2007, Parker et al. 2008, Wegner et al. 2008, Welbergen et al. 2008, Pelini et al. 2009).

Many traits also show plasticity (Pigliucci 2005), which can result in the alteration of direct and indirect interactions among individuals and their environments, so affecting population and community dynamics, and aspects of community and ecosystem functioning (Pertoldi et al. 2007). Hence, to predict the biological outcome of an environmental change, understanding the magnitude and direction of phenotypic plasticity (i.e. the potential of individuals to respond over the short term) and the speed at which the population can evolve (i.e. the potential of the population to respond over the long term) is also important. Although plasticity is often viewed as a likely way that organisms can deal with climate change, the effectiveness of this strategy depends on whether organisms can predict stressful conditions. Phenotypic plasticity can be interpreted as a bet-hedging strategy in an unpredictable environment (Simons \& Johnston 1997). When the magnitude of genetic variation is insufficient to create a diversity of phenotypes that can be exposed to selection, phenotypic plasticity, by producing variation within populations, will enrich the evolutionary potential. However, phenotypic plasticity can also reduce the ability for evolutionary adaptation (see van Buskirk \& Steiner 2009). Moreover, the genetic constitution of a specific population might significantly affect its ability to respond to changing environmental conditions via plasticity. For example, small populations exposed to genetic drift and inbreeding may be less plastic; a phenomenon described by Fowler \& Whitlock (1999) as inbreeding depression for canalisation (Fig. 2). Few experiments examine the significance of this phenomenon for traits of physiological importance in natural populations. Unpredictable thermal variation should lead not only to a broadening of performance curves, but also to a reduction in phenotypic plasticity (Kingsolver \& Huey 1998, Deere \& Chown 2006, Angilletta 2009). Thus, in areas where climate change involves a decline in the predictability of extremes, populations that currently show considerable plasticity may face high costs because of inappropriate responses. Moreover, these costs may differ considerably among life stages because of the variation in strategies and the significance of behavioural adjustment among them (e.g. Huey et al. 2003, Marais \& Chown 2008). Understanding the significance of extreme events remains a pressing, yet under-investigated, issue (see Schwager et al. 2006, Chown \& Terblanche 2007 for further discussion).

Importantly, climate change will affect several environmental parameters simultaneously. Thus populations are likely to encounter concurrent changes in

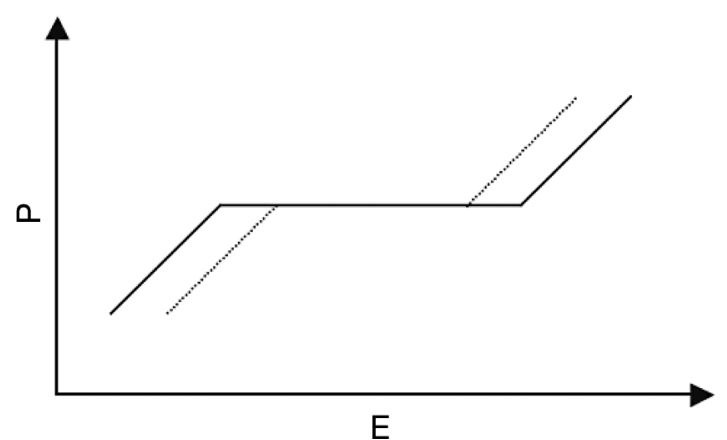

Fig. 2. Schematic illustration of canalization. For a given genotype, the phenotype $(\mathrm{P})$ is a non-linear function of the environment (E), as shown by the solid line. For a 'normal' range of environments, the genotype shows no phenotypic variation, but variation exists outside this range. If canalization is reduced, e.g. by inbreeding, then this 'zone of canalization' is narrowed, as shown by the dotted line. The result is more environmental variance in the population (modified after Lewontin 1974) 
temperature, water availability and resource supply. Furthermore, environmental stress may cause a pronounced reduction in effective population size and, in consequence, reduce evolutionary potential and increase inbreeding rate. Typically, laboratory investigations do not adopt a multifactorial approach, preferring to vary one parameter while holding others constant, which may constrain the ecological relevance of such studies (Gibbs 1999, Harshman \& Hoffmann 2000). However, multifactor assessments will be important for understanding future responses. Not only is variation in performance curves associated with such interactions (see above), but multi-factor assessments may reveal trait-environment and genotype-environment interactions that limit responses to change. Genotype-environment interactions for a trait within a population suggest genetic variation for phenotypic plasticity, and will increase the phenotypic variance of the trait, which will depress the response to selection (Pertoldi \& Bach 2007). There is ample evidence for trait interactions limiting responses to selection (Etterson \& Shaw 2001, Blows et al. 2004).

Moreover, synergistic interactions among climate and other factors are expected (Brook et al. 2008). Although evidence for ecological synergies is limited at present (Darling \& Côté 2008), multivariate studies are starting to emerge (e.g. Hayward et al. 2001, Juliano et al. 2002, Chown et al. 2007, Hoverman \& Relyea 2007, Campero et al. 2008, Kristensen et al. 2008a, Liu et al. 2009). Ultimately, the need for replication limits the number of factors that can be examined in one experiment to no more than a few. Common garden experiments, field releases of manipulated organisms, and mesocosm trials provide useful ways of overcoming these experimental limitations, because the more natural conditions represent a multifactor change in the environment (Loeschcke \& Hoffmann 2007, Kristensen et al. 2008a,b, Gaston et al. 2009, Overgaard et al. 2010). Whilst the ultimate cause of the response may not always be detectable from these approaches, this cause might be elucidated by combining experiments under natural conditions with laboratory experiments.

\section{POTENTIAL AND REALIZED EVOLUTION DURING CLIMATE CHANGE}

Despite the complexity of selective factors in changing environments, evolutionary responses are well documented. The earliest examples include the evolution of metal tolerance in plants and the evolution of pesticide tolerance in insects (Bishop \& Cook 1981). More recently, rapid evolutionary changes during the course of biological invasions have also been observed
(Strauss et al. 2006, Carroll \& Fox 2007). Substantial phenotypic responses to climate change have been documented for several traits (e.g. Walther et al. 2002, Convey et al. 2003, Perry et al. 2005, Bradshaw \& Holzapfel 2006, Millien et al. 2006, Babin-Fenske et al. 2008), and it has also been shown that species which appear incapable of responding are suffering adverse consequences (Møller et al. 2008, Ozgul et al. 2009). However, only a few studies have so far demonstrated a genetic basis to these responses (Nussey et al. 2005, Umina et al. 2005, Bradshaw \& Holzapfel 2008), and it is not yet clear to what extent phenotypic changes reflect plasticity or evolutionary change (Gienapp et al. 2007, 2008). Indeed, recent studies of red-billed gulls and Soay sheep failed to document evidence for genetic change, despite large, climate-associated declines in body size (Teplitsky et al. 2008, Ozgul et al. 2009).

For the traits typically investigated by evolutionary physiologists, evidence of climate-induced evolution is limited (Gienapp et al. 2008). Nevertheless, a few studies have had the power to detect evolutionary adaptation to climate change (Bradshaw \& Holzapfel 2001, Franks et al. 2007, Hoffmann \& Daborn 2007). Where evolutionary changes have not been detected, plastic changes might have compensated for the demographic impacts of climate change, as in the case of birds shifting their nesting time in response to food availability (Teplitsky et al. 2008). Despite the relative lack of empirical evidence to date, rapid evolution of phenotypes and their plasticity is expected from theoretical models (see reviews in Ghalambor et al. 2007, Angilletta 2009). Moreover, it has also been widely documented in laboratory studies of responses to environmental temperature and water availability (e.g. Bennett et al. 1992, Cavicchi et al. 1995, Bull et al. 2000, Gibbs et al. 2003, Bubliy \& Loeschcke 2005, Driessen et al. 2007, Sørensen et al. 2007, Vera et al. 2008).

Plastic changes have an underlying genetic basis and the extent of plasticity may thus also evolve (Scheiner 2002, Driessen et al. 2007). For example, Nussey et al. (2005) showed that great tits Parus major in the Netherlands have increased their phenotypic plasticity to cope with more unpredictable spring weather in the Netherlands over the last $32 \mathrm{yr}$. This is one example illustrating heritable genetic variation for the ability to respond in a plastic manner. However, estimates of heritability and variance components for the physiological mechanisms underlying plastic responses (Krebs et al. 1998) are scarce.

A problem in extrapolating from laboratory studies to likely field responses is that the traits characterized under laboratory conditions might not be relevant to field ecology. Two issues related to the measurement of heat tolerance illustrate this point. First, the rates of 
evolution in response to heat stress will depend on how this trait is measured. Recent studies of tsetse flies, vinegar flies and Argentine ants have shown that the rate of controlled thermal change, part of the procedure for estimating critical thermal limits, affects not only the mean thermal limit but also its variance and acclimation potential (Terblanche et al. 2007, Chown et al. 2009, Mitchell \& Hoffmann 2010). The latter study showed that substantial differences in phenotypic variance emerged when rates of thermal change were varied, influencing the heritability and evolvability of traits. These findings underscore the need to document rates of environmental change appropriate to the organism of interest (see also Sinclair 2001). The second issue is that measures of heat tolerance can be quite poorly correlated, underscoring the importance of measuring tolerance in a meaningful way. In Drosophila, intraspecific comparisons have revealed limited evidence for genetic correlations between traits such as knockdown resistance and mortality rate (Hoffmann et al. 1997, Berrigan \& Hoffmann 1998), suggesting that different genetic mechanisms underlie these traits (Hoffmann et al. 2003b, Rako et al. 2007, but see Sørensen et al. 2007). Yet correlations between these traits do appear at the interspecific level (Hori \& Kimura 1998, Berrigan 2000, Mitchell \& Hoffmann 2010), which may reflect patterns of correlated selection rather than genetic correlations.

The potential for adaptation can also be usefully explored within a demographic framework. When population sizes fluctuate or are small, the potential for demographic extinction exists even when populations might possess genetic variation for adaptation (Burger \& Lynch 1995). Moreover, if effective population size is small, the amount of heritable variation may be limited and selection could be overwhelmed by genetic drift, making all phenotypes or alleles effectively selectively neutral (Lynch 1996). Thus the population may be unable to evolve in response to selection, leaving it vulnerable to demographic and environmental stochasticity, which might, in consequence, be the dominant factor in determining the fate of small populations (Drake \& Lodge 2004, Hoarau 2005).

As population size increases, evolutionary change becomes possible, but adaptation might nevertheless be opposed by gene flow and genetic drift during a population bottleneck (Holt et al. 2003, 2004), and perhaps further confounded by inbreeding depression. These different components have rarely been compared within the context of adaptation to climate change. In a recent study, Willi \& Hoffmann (2009) examined the relative impacts of heat stress and demographic factors on experimental populations of Drosophila birchii. Demographic factors were more important in small populations (20 flies), whereas heritable variation for dealing with heat stress became important in larger populations (100 flies) and predominated in even larger populations (1000 flies). Although most traits that have been examined in model organisms (e.g. D. melanogaster) vary genetically within populations, the results of Mitchell \& Hoffmann (2010) suggest that this is not always the case. Moreover, the situation becomes more complicated when different species are compared. For example, tropical species of Drosophila that are sensitive to desiccation have little genetic variation for desiccation resistance when compared to more widespread species that were less sensitive (Kellermann et al. 2009). Similar comparative data for other taxa are urgently required.

Small population size can also lead to inbreeding, and inbreeding depression is often more severe under stressful environmental conditions (reviewed in Armbruster \& Reed 2005). Thus climatic conditions that are considered benign for a large population may be highly stressful for a smaller population of the same species. Liao \& Reed (2009) found that inbreeding by environment interactions affected extinction risk for a wide range of population sizes and substantially reduced the mean persistence time, compared to a situation where such interactions were not included. Thus, apart from considering synergistic interactions between environmental factors, interactions between genetic and environmental factors should be considered in future empirical and modelling studies as they are likely have strong impacts on the distribution of performance curves.

Because the effects of climate change on the environment can be complex and involve altered biotic interactions, adaptation may be slowed by the multiple genetic changes that might be required (Van Doorslaer et al. 2009). Thus not only could responses to selection be constrained by genetic correlations among traits (Blows et al. 2004) and by patterns of gene flow (Kirkpatrick \& Barton 1997, Holt et al. 2003, Bridle et al. 2009), but they might also be slowed by the fact that the right combination of alleles for adapting to new conditions is not available. Moreover, even when genetic variation is present, the environment can affect the expression thereof, such that it is not expressed when phenotypic selection is most intense (Robinson et al. 2009).

\section{THE BROADER CONTEXT}

As indicated by the preceding discussion, the demographic context of phenotypic variation has considerable significance to the process of adaptation. Not only does dispersal among patches influence the evolution of traits and their plasticity, but the changing meta- 
community also plays a role in determining how populations respond to change (reviewed in Chown \& Terblanche 2007, Angilletta 2009; see also Holt \& Keitt 2000, Ricklefs 2008, Tylianakis et al. 2008, Mitchell \& Angilletta 2009). Given this situation, predictions at the community level seem either pointless at present or unworthy of pursuit (see Lawton 1999, Simberloff 2004, Ricklefs 2008), especially since initial conditions, instabilities and model errors should greatly affect the predicted impact of climate change on ecological communities. Nonetheless, one might still have hope for forecasting the impacts of climate change on species or populations (or more broadly at the landscape and macroecological levels).

Mahlman's (1998) pinball-machine-thought experiment provides a useful analogy for this situation. In the game, the path of the ball is unpredictable after a few collisions with the machine's bumpers, but at some point the ball will end up in the gutter. The odds of the ball ending up in the gutter can be altered dramatically by changing the slope of the playing field. In this latter scenario, the trajectory of the ball remains as unpredictable as before the change in slope. Nevertheless, one can predict that the ball will require more time to reach the gutter. Forecasting the impact of climate change on diversity can be viewed in a similar fashion: many of the details of ensuing interactions will not be especially clear, but the general trends should be reasonably comprehensible.

Currently, 2 broad approaches are available for understanding the interplay between physiology and the environment, and perhaps for forecasting responses to climate change within a broader context. The first, 'analytical' approach amounts to scaling up spatially explicit studies by adopting an $r \times C$ matrix perspective (Gaston et al. 2008, 2009). Traditionally, cells of such a matrix would comprise the presences/ absences of species or their respective abundances at a series of sites (e.g. Bell 2003). However, the matrix can be populated with virtually any variable, such as critical thermal maximum of a series of populations. In a spatially explicit form, spatial variation in an environmental factor (e.g. mean temperature) might form the first matrix. With an appropriate function relating the environmental variable to survival or growth rate, these data might be translated into a matrix of predicted abundances. The function matrix could be considered invariant across space, time or taxonomy (niche conservatism; see Wiens \& Graham 2005). Alternatively, spatial variation in the function matrix might reflect predicted or realized phenotypic plasticity, which in turn could be associated with a matrix containing dispersal rates among populations. Formal mathematical approaches for investigating the relationships among matrices and for identifying signifi- cant variation in parameters are available (see Dray \& Legendre 2008). Likewise, characteristics of matrices, such as nestedness, can be analyzed to assess the roles that various factors play in structuring assemblages. Clearly, such an approach is closely related to physiologically based models of species' distributions (Kearney \& Porter 2009), crop performance models (e.g. Brisson et al. 1992), spatially explicit population viability modelling (e.g. Carroll 2007), landscape ecology (e.g. Werner et al. 2009) and landscape genetics (Balkenhol et al. 2009).

The second, 'simulation' approach (or general simulation modelling [GSM]), is similar to the analytical approach in the sense that it is spatially explicit and adopts a series of Cartesian layers (Gotelli et al. 2009). However, the simulation approach diverges at this point in a way that avoids problems associated with curve fitting and parameters associated with the concatenation of multiple species models. In essence, the simulation approach involves the settings of 3 'control knobs': dispersal limitation, evolutionary origins and environmental gradients. Whilst these factors are the basic settings, multiple controls are clearly required for each (e.g. Gotelli et al. 2009). The GSM makes relatively few assumptions, as do models of geometric constraints (see Currie \& Kerr 2008) and, at least from a 'first order perspective', as does the metabolic theory of ecology (Brown et al. 2004). The GSM approach therefore makes a useful addition to the suite of approaches available to predict the likely impacts of climate change, although it has yet to be tested. A comparison of the outcomes of the GSM and analytical matrix approaches to the same set of data might prove especially informative (see Zurell et al. 2009 for an analogous approach).

\section{CONSERVATION IMPLICATIONS}

Determining the biodiversity impacts of climate change is a considerable challenge (Schwenk et al. 2009). Clearly, evolutionary physiology has much to offer in this undertaking. For example, the suggestions that tropical ectotherms might face the greatest risk of extinction from warming (and drying) and might lack the genetic variation to adapt (Hoffmann et al. 2003a, Kellermann et al. 2009) draws immediate attention to the conservation needs of these organisms, which were previously considered to be at less risk than ectotherms in other regions. A demonstration of the significance of shade to many species for physiological regulation, and patterns of habitat conversion, provide further grounds for concern (Kearney et al. 2009b).

As reviewed here, substantial shifts in the ranges and phenologies of species from an array of groups 
have occurred in response to climate change (Walther et al. 2002, Parmesan \& Yohe 2003, Nussey et al. 2005, Parmesan 2006, Lenoir et al. 2008, Chen et al. 2009, Steltzer \& Post 2009). These observations emphasise the importance of mitigating such shifts by maintaining corridors or by securing large areas with suitable habitats for wildlife. Without such initiatives, many populations may become extinct due to combined effects of environmental stress, lack of evolutionary potential and inbreeding depression.

Evolutionary physiology can also make valuable contributions to other areas. For example, the effects of anthropogenically assisted biological invasions and climate-induced range shifts will be increasingly difficult to separate (Tolley et al. 2008, Walther et al. 2009). Physiologically based models of species' distributions coupled with investigations of the success of particular genotypes during environmental change may provide one means of separating human- and climate-induced range shifts, especially since these genotypic differences have a profound effect on the success of invasions (Keller \& Taylor 2008) as well as on current ability to forecast their ranges in new areas (MauCrimmins et al. 2006, Fitzpatrick et al. 2007, Duncan et al. 2009). Similarly, much attention is focused on assisted translocation (Richardson et al. 2009). Whilst this strategy will be useful for only a minority of species designated of special interest, investigations of likely demographic success in new areas will have to consider the physiological capabilities of the species. Moreover, although assisted translocation of entire species may be difficult, translocation of genotypes adapted to different conditions is likely to be much more feasible and might provide an insurance policy against future change (Broadhurst et al. 2008, Hedrick \& Fredrickson 2010, but see Bijlsma et al. 2010). In this regard, assessments of movements of individuals into areas perhaps already occupied by other populations of the species may have to move away from the consideration of neutral markers only (which will show differences based mostly on time of isolation) and consider genes that are likely to have significance in the context of environmental responses (Demontis et al. 2009, Pertoldi et al. 2010). Genome-based evolutionary physiology has much to offer here too. For example, genome-wide breeding strategies can be used on captive populations of endangered species before translocation into the wild to optimize genetic variability in physiologically important parts of the genome (Pertoldi et al. 2010).

Acknowledgments. S. Clusella-Trullas kindly allowed us to modify a performance curve figure she had drawn, and 2 anonymous reviewers provided comments on a previous version of the manuscript. Several of the ideas expressed here emerged from discussions at the European Science Foundation-funded workshop entitled 'Evolutionary and physiological adaptation to climate-induced environmental changes' held in Białowieża, Poland, July 2009. We are grateful to the participants for their insights and thoughtful participation. S.L.C. thanks The University of Melbourne for its hospitality during the drafting of this manuscript.

\section{LITERATURE CITED}

Adler RF, Gu G, Wang JJ, Huffman GJ, Curtis S, Bolvin D (2008) Relationships between global precipitation and surface temperature on interannual and longer timescales (1979-2006). J Geophys Res 113:D22104 doi:10.1029/2008 JD010536

Allen AP, Brown JH, Gillooly JF (2002) Global biodiversity, biochemical kinetics, and the energetic-equivalence rule. Science 297:1545-1548

Angilletta MJ Jr (2009) Thermal adaptation: a theoretical and empirical synthesis. Oxford University Press, Oxford

> Angilletta MJ Jr, Niewiarowski PH, Navas CA (2002) The evolution of thermal physiology in ectotherms. J Therm Biol 27:249-268

> Angilletta MJ Jr, Bennett AF, Guderley H, Navas CA, Seebacher F, Wilson RS (2006) Coadaptation: a unifying principle in evolutionary thermal biology. Physiol Biochem Zool 79:282-294

Archer D, Rahmstorf S (2010) The climate crisis. An introductory guide to climate change. Cambridge University Press, Cambridge

> Armbruster P, Reed DH (2005) Inbreeding depression in benign and stressful environments. Heredity 95:235-242

Austin M (2007) Species distribution models and ecological theory: a critical assessment and some possible new approaches. Ecol Model 200:1-19

Babin-Fenske J, Anand M, Alarie Y (2008) Rapid morphological change in stream beetle museum specimens correlates with climate change. Ecol Entomol 33:646-651

Balkenhol N, Waits LP, Dezzani RJ (2009) Statistical approaches in landscape genetics: an evaluation of methods for linking landscape and genetic data. Ecography 32: 818-830

Beale CM, Lennon JJ, Gimona A (2008) Opening the climate envelope reveals no macroscale associations with climate in European birds. Proc Natl Acad Sci USA 105: 14908-14912

> Bell G (2003) The interpretation of biological surveys. Proc R Soc Lond B 270:2531-2542

> Bennett AF, Lenski RE, Mittler JE (1992) Evolutionary adaptation to temperature. I. Fitness responses of Escherichia coli to changes in its thermal environment. Evolution 46:16-30

Berrigan D (2000) Correlations between measures of thermal stress resistance within and between species. Oikos 89: 301-304

Berrigan D, Hoffmann AA (1998) Correlations between measures of heat resistance and acclimation in two species of Drosophila and their hybrids. Biol J Linn Soc 64:449-462

Bijlsma R, Westerhof MDD, Roekx LP, Pen I (2010) Dynamics of genetic rescue in inbred Drosophila melanogaster populations. Conserv Genet 11:449-462

Bishop J, Cook L (1981) Genetic consequences of man-made change. Academic Press, London

Blows MW, Chenoweth S, Hine E (2004) Orientation of the genetic variance-covariance matrix and the fitness surface for multiple male sexually selected traits. Am Nat 163: $329-340$ 
Bonan G (2002) Ecological climatology: concepts and applications, 1st edn. Cambridge University Press, Cambridge

Bonier F, Martin PR, Wingfield JC (2007) Urban birds have broader environmental tolerance. Biol Lett 3:670-673

> Both C, Bouwhuis S, Lessells CM, Visser ME (2006) Climate change and population declines in a long-distance migratory bird. Nature 441:81-83

Bradshaw WE, Holzapfel CM (2001) Genetic shift in photoperiodic response correlated with global warming. Proc Natl Acad Sci USA 98:14509-14511

Bradshaw WE, Holzapfel CM (2006) Evolutionary response to rapid climate change. Science 312:1477-1478

Bradshaw WE, Holzapfel CM (2008) Genetic responses to rapid climate change: it's seasonal timing that matters. Mol Ecol 17:157-166

Bridle JR, Polechová J, Vines TH (2009) Limits to adaptation and patterns of biodiversity. In: Butlin R, Bridle J, Schluter $\mathrm{D}$ (eds) Speciation and patterns of diversity. Cambridge University Press, Cambridge, p 77-101

Brisson N, Sguin B, Bertuzzi P (1992) Agrometeorological soil-water balance for crop simulation models. Agric For Meteorol 59:267-287

Broadhurst LM, Lowe A, Coates DJ, Cunningham SA, McDonald M, Vesk PA, Yates C (2008) Seed supply for broadscale restoration: maximizing evolutionary potential. Evol Appl 1:587-597

Brook BW, Sodhi NS, Bradshaw CJA (2008) Synergies among extinction drivers and global change. Trends Ecol Evol 23: 453-460

Brooker RW, Travis JMJ, Clark EJ, Dytham C (2007) Modelling species' range shifts in a changing climate: the impacts of biotic interactions, dispersal distance and the rate of climate change. J Theor Biol 245:59-65

Brown CR, Brown MB (1998) Intense natural selection on body size and wing and tail asymmetry in cliff swallows during severe weather. Evolution 52:1461-1475

> Brown JH, Gillooly JF, Allen AP, Savage V, West GB (2004) Toward a metabolic theory of ecology. Ecology 85: 1771-1789

Bubliy OA, Loeschcke V (2005) Correlated responses to selection for stress resistance and longevity in a laboratory population of Drosophila melanogaster. J Evol Biol 18: 789-803

Buckley LB (2008) Linking traits to energetics and population dynamics to predict lizard ranges in changing environments. Am Nat 171:E1-E19

Bull JJ, Badgett MR, Wichman HA (2000) Big-benefit mutations in a bacteriophage inhibited with heat. Mol Biol Evol 17:942-950

Burger R, Lynch M (1995) Evolution and extinction in a changing environment: a quantitative-genetic analysis. Evolution 49:151-163

> Campero M, de Block M, Ollevier F, Stoks R (2008) Correcting the short-term effect of food deprivation in a damselfly: mechanisms and costs. J Anim Ecol 77:66-73

- Carroll C (2007) Interacting effects of climate change, landscape conversion, and harvest on carnivore populations at the range margin: marten and lynx in the northern Appalachians. Conserv Biol 21:1092-1104

> Carroll SP, Fox CW (2007) Dissecting the evolutionary impacts of plant invasions: bugs and beetles as native guides. Global Change Biol 13:1644-1657

- Cavicchi S, Guerra D, La Torre V, Huey RB (1995) Chromosonal analysis of heat-shock tolerance in Drosophila melanogaster evolving at different temperatures in the laboratory. Evolution 49:676-684

Chen IC, Shiu H, Benedick S, Holloway JD and others (2009)
Elevation increases in moth assemblages over 42 years on a tropical mountain. Proc Natl Acad Sci USA 106: 1479-1483

> Chown SL (2001) Physiological variation in insects: hierarchical levels and implications. J Insect Physiol 47:649-660

> Chown SL, Gaston KJ (2008) Macrophysiology for a changing world. Proc R Soc Lond B 275:1469-1478

Chown SL, Terblanche JS (2007) Physiological diversity in insects: ecological and evolutionary contexts. Adv Insect Physiol 33:50-152

Chown SL, Gaston KJ, Robinson D (2004) Macrophysiology: large-scale patterns in physiological traits and their ecological implications. Funct Ecol 18:159-167

> Chown SL, Slabber S, McGeoch MA, Janion C, Leinaas HP (2007) Phenotypic plasticity mediates climate change responses among invasive and indigenous arthropods. Proc R Soc Lond B 274:2531-2537

Chown SL, Jumbam KR, Sørensen JG, Terblanche JS (2009) Phenotypic variance, plasticity and heritability estimates of critical thermal limits depend on methodological context. Funct Ecol 23:133-140

- Clarke A, Gaston KJ (2006) Climate, energy and diversity. Proc R Soc Lond B 273:2257-2266

Convey P, Block W, Peat HJ (2003) Soil arthropods as indicators of water stress in Antarctic terrestrial habitats? Global Change Biol 9:1718-1730

Crozier L, Dwyer G (2006) Combining population-dynamic and ecophysiological models to predict climate-induced insect range shifts. Am Nat 167:853-866

Currie DJ, Kerr JT (2008) Tests of the mid-domain hypothesis: a review of the evidence. Ecol Monogr 78:3-18

> Darling ES, Côté IM (2008) Quantifying the evidence for ecological synergies. Ecol Lett 11:1278-1286

> Davis MB, Shaw RG (2001) Range shifts and adaptive responses to quaternary climate change. Science 292:673-679

> Davis AJ, Jenkinson LS, Lawton JH, Shorrocks B, Wood S (1998) Making mistakes when predicting shifts in species range in response to global warming. Nature 391:783-786

> Davis MB, Shaw RG, Etterson JR (2005) Evolutionary responses to changing climate. Ecology 86:1704-1714

de Jong G, van der Have TM (2008) Temperature dependence of development rate, growth rate and size: from biophysics to adaptation. In: Whitman DW, Ananthakrishnan TN (eds) Phenotypic plasticity of insects: mechanisms and consequences. Science Publishers, Enfield, NH, p 461-526

> de Mazancourt C, Johnson E, Barraclough TG (2008) Biodiversity inhibits species' evolutionary responses to changing environments. Ecol Lett 11:380-388

> Deere JA, Chown SL (2006) Testing the beneficial acclimation hypothesis and its alternatives for locomotor performance. Am Nat 168:630-644

> Demontis D, Pertoldi C, Loeschcke V, Mikkelsen K, Axelsson T, Kristensen TN (2009) Efficiency of selection, as measured by SNP variation, is dependent on inbreeding rate in Drosophila melanogaster. Mol Ecol 18:4551-4563

> Deutsch CA, Tewksbury JJ, Huey RB, Sheldon KS, Ghalambor CK, Haak DC, Martin PR (2008) Impacts of climate warming on terrestrial ectotherms across latitude. Proc Natl Acad Sci USA 105:6668-6672

Drake JM, Lodge DM (2004) Effects of environmental variability on extinction and establishment. Ecol Lett 7:26-30

> Dray S, Legendre P (2008) Testing the species traits-environment relationships: the fourth-corner problem revisited. Ecology 89:3400-3412

Driessen G, Ellers J, van Straalen NM (2007) Variation, selection and heritability of thermal reaction norms for juvenile growth in Orchesella cincta (Collembola: Entomobryidae). 
Eur J Entomol 104:39-46

Duncan RP, Cassey P, Blackburn TM (2009) Do climate envelope models transfer? A manipulative test using dung beetle introductions. Proc R Soc Lond B 276:1449-1457

- Dynesius M, Jansson R (2000) Evolutionary consequences of changes in species' geographical distributions driven by Milankovitch climate oscillations. Proc Natl Acad Sci USA 97:9115-9120

Easterling DR, Meehl GA, Parmesan C, Changnon SA, Karl TR, Mearns LO (2000) Climate extremes: observations, modeling, and impacts. Science 289:2068-2074

Elith J, Graham CH (2009) Do they? How do they? Why do they differ? On finding reasons for differing performances of species distribution models. Ecography 32:66-77

Elith J, Graham CH, Anderson RP, Dudík M and others (2006) Novel methods improve prediction of species' distributions from occurrence data. Ecography 29:129-151

Etterson JR, Shaw RG (2001) Constraint to adaptive evolution in response to global warming. Science 294:151-154

> Feder ME, Hofmann GE (1999) Heat-shock proteins, molecular chaperones, and the stress response: evolutionary and ecological physiology. Annu Rev Physiol 61:243-282

$>$ Feder ME, Bennett AF, Huey RB (2000) Evolutionary physiology. Annu Rev Ecol Syst 31:315-341

> Fitzpatrick MC, Weltzin JF, Sanders NJ, Dunn RR (2007) The biogeography of prediction error: Why does the introduced range of the fire ant over-predict its native range? Global Ecol Biogeogr 16:24-33

> Fowler K, Whitlock MC (1999) The distribution of phenotypic variance with inbreeding. Evolution 53:1143-1156

Franks SJ, Sim S, Weis AE (2007) Rapid evolution of flowering time by an annual plant in response to a climate fluctuation. Proc Natl Acad Sci USA 104:1278-1282

Gaston KJ (2003) The structure and dynamics of geographic ranges. Oxford University Press, Oxford

> Gaston KJ (2009) Geographic range limits: achieving synthesis. Proc R Soc Lond B 276:1395-1406

> Gaston KJ, Chown SL, Evans KL (2008) Ecogeographic rules: elements of a synthesis. J Biogeogr 35:483-500

Gaston KJ, Chown SL, Calosi P, Bernardo J and others (2009) Macrophysiology: a conceptual re-unification. Am Nat 174:595-612

Genner MJ, Sims DW, Wearmouth VJ, Southall EJ, Southward AJ, Henderson PA, Hawkins SJ (2004) Regional climatic warming drives long-term community changes of British marine fish. Proc R Soc Lond B 271:655-661

Ghalambor CK, McKay JK, Carroll SP, Reznick DN (2007) Adaptive versus non-adaptive phenotypic plasticity and the potential for contemporary adaptation in new environments. Funct Ecol 21:394-407

Gibbs AG (1999) Laboratory selection for the comparative physiologist. J Exp Biol 202:2709-2718

Gibbs AG, Fukuzato F, Matzkin LM (2003) Evolution of water conservation mechanisms in Drosophila. J Exp Biol 206: 1183-1192

Gienapp P, Leimu R, Merilä J (2007) Responses to climate change in avian migration time-microevolution versus phenotypic plasticity. Clim Res 35:25-35

Gienapp P, Teplitsky C, Alho JS, Mills JA, Merilä J (2008) Climate change and evolution: disentangling environmental and genetic responses. Mol Ecol 17:167-178

$>$ Gilchrist GW (1995) Specialists and generalists in changing environments. I. Fitness landscapes of thermal sensitivity. Am Nat 146:252-270

Gilchrist GW, Huey RB (1999) The direct response of Drosophila melanogaster to selection on knockdown temperature. Heredity 83:15-29
Gotelli NJ, Anderson MJ, Arita HT, Chao A and others (2009) Patterns and causes of species richness: a general simulation model for macroecology. Ecol Lett 12:873-886

> Grant BR, Grant PR (1993) Evolution of Darwin's finches caused by a rare climatic event. Proc R Soc Lond B 251: 111-117

> Gutschick VP, BassiriRad H (2003) Extreme events as shaping physiology, ecology, and evolution of plants: toward a unified definition and evaluation of their consequences. New Phytol 160:21-42

> Harshman LG, Hoffmann AA (2000) Laboratory selection experiments using Drosophila: What do they really tell us? Trends Ecol Evol 15:32-36

> Hayward SAL, Bale JS, Worland MR, Convey P (2001) Influence of temperature on the hygropreference of the collembolan, Cryptopygus antarcticus, and the mite, Alaskozetes antarcticus from the maritime Antarctic. J Insect Physiol 47:11-18

> Hedrick PW, Fredrickson R (2010) Genetic rescue guidelines with examples from Mexican wolves and Florida panthers. Conserv Genet 11:615-626

> Helmuth B, Kingsolver JG, Carrington E (2005) Biophysics, physiological ecology, and climate change: Does mechanism matter? Annu Rev Physiol 67:177-201

> Helmuth B, Mieszkowska N, Moore P, Hawkins SJ (2006) Living on the edge of two changing worlds: forecasting the responses of rocky intertidal ecosystems to climate change. Annu Rev Ecol Evol Syst 37:373-404

Hijmans RJ, Graham CH (2006) The ability of climate envelope models to predict the effect of climate change on species distributions. Global Change Biol 12:2272-2281

> Hill JK, Thomas CD, Huntley B (1999) Climate and habitat availability determine 20th century changes in a butterfly's range margin. Proc R Soc Lond B 266:1197-1206

Hoarau G (2005) Low effective population size and evidence for inbreeding in an overexploited flatfish, plaice (Pleuronectes platessa L.). Proc R Soc Lond B 272:497-503

Hochachka PW, Somero GN (2002) Biochemical adaptation. Mechanism and process in physiological evolution. Oxford University Press, New York

> Hoffmann AA (2010) Physiological climatic limits in Drosophila: patterns and implications. J Exp Biol 213:870-880

Hoffmann AA, Blows MW (1994) Species borders: ecological and evolutionary perspectives. Trends Ecol Evol 9:223-227

> Hoffmann AA, Daborn PJ (2007) Towards genetic markers in animal populations as biomonitors for human-induced environmental change. Ecol Lett 10:63-76

Hoffmann AA, Parsons PA (1997) Extreme environmental change and evolution. Cambridge University Press, Cambridge

Hoffmann AA, Dagher H, Hercus M, Berrigan D (1997) Comparing different measures of heat resistance in selected lines of Drosophila melanogaster. J Insect Physiol 43: 393-405

- Hoffmann AA, Hallas RJ, Dean JA, Schiffer M (2003a) Low potential for climatic stress adaptation in a rainforest Drosophila species. Science 301:100-102

Hoffmann AA, Sørensen JG, Loeschcke V (2003b) Adaptation of Drosophila to temperature extremes: bringing together quantitative and molecular approaches. J Therm Biol 28: $175-216$

> Holt RD, Keitt TH (2000) Alternative causes for range limits: a metapopulation perspective. Ecol Lett 3:41-47

> Holt RD, Lawton JH, Gaston KJ, Blackburn TM (1997) On the relationship between range size and local abundance: back to the basics. Oikos 78:183-190

Holt RD, Gomulkiewicz R, Barfield M (2003) The pheno- 
menology of niche evolution via quantitative traits in a 'black-hole' sink. Proc R Soc Lond B 270:215-224

Holt RD, Barfield M, Gomulkiewicz R (2004) Temporal variation can facilitate niche evolution in harsh sink environments. Am Nat 164:187-200

Hori Y, Kimura MT (1998) Relationship between cold stupor and cold tolerance in Drosophila (Diptera: Drosophilidae). Environ Entomol 27:1297-1302

Hoverman JT, Relyea RA (2007) How flexible is phenotypic plasticity? Developmental windows for trait induction and reversal. Ecology 88:693-705

Huey RB, Stevenson RD (1979) Integrating thermal physiology and ecology of ectotherms: a discussion of approaches. Am Zool 19:357-366

Huey RB, Hertz PE, Sinervo B (2003) Behavioral drive versus behavioral inertia in evolution: a null model approach. Am Nat 161:357-366

Huey RB, Deutsch CA, Tewksbury JJ, Vitt LJ, Hertz PE, Álvarez Pérez HJ, Garland T Jr (2009) Why tropical forest lizards are vulnerable to climate warming. Proc R Soc Lond B 276:1939-1948

IEA (International Energy Agency) (2009) How the energy sector can deliver on a climate agreement in Copenhagen. Special early excerpt of the World Energy Outlook 2009 for the Bangkok UNFCCC meeting. IEA, Paris

IPCC (2000) Summary for policymakers. Special report on emissions scenarios. IPCC, Geneva

IPCC (2007) Summary for policymakers. In: Solomon S, Qin D, Manning M, Chen Z and others (eds) Climate change 2007: the physical science basis. Contribution of Working Group I to the Fourth Assessment Report of the Intergovernmental Panel on Climate Change. Cambridge University Press, Cambridge

Jentsch A, Beierkuhnlein C (2008) Research frontiers in climate change: effects of extreme meteorological events on ecosystems. C R Geosci 340:621-628

> Jentsch A, Kreyling J, Beierkuhnlein C (2007) A new generation of climate-change experiments: events, not trends. Front Ecol Environ 5:365-374

> Jeschke JM, Strayer DL (2008) Usefulness of bioclimatic models for studying climate change and invasive species. Ann NY Acad Sci 1134:1-24

> Juliano SA, O'Meara GF, Morrill JR, Cutwa MM (2002) Desiccation and thermal tolerance of eggs and the coexistence of competing mosquitoes. Oecologia 130:458-469

Katz RW, Brown BG (1992) Extreme events in a changing climate: variability is more important than averages. Clim Change 21:289-302

Kearney M, Porter W (2009) Mechanistic niche modelling: combining physiological and spatial data to predict species' ranges. Ecol Lett 12:334-350

Kearney M, Phillips BL, Tracy CR, Christian KA, Betts G, Porter WP (2008) Modelling species distributions without species distributions: the cane toad in Australia under current and future climates. Ecography 31:423-434

Kearney M, Porter WP, Williams C, Ritchie S, Hoffmann AA (2009a) Integrating biophysical models and evolutionary theory to predict climatic impacts on species' ranges: the dengue mosquito Aedes aegypti in Australia. Funct Ecol 23:528-538

Kearney M, Shine R, Porter WP (2009b) The potential for behavioral thermoregulation to buffer 'cold-blooded' animals against climate warming. Proc Natl Acad Sci USA 106:3835-3840

Keith DA, Akçakaya HR, Thuiller W, Midgley GF and others (2008) Predicting extinction risks under climate change: coupling stochastic population models with dynamic bio- climatic habitat models. Biol Lett 4:560-563

> Keller SR, Taylor DR (2008) History, chance and adaptation during biological invasion: separating stochastic phenotypic evolution from response to selection. Ecol Lett 11: 852-866

Kellermann V, van Heerwaarden B, Sgrò C, Hoffmann AA (2009) Fundamental evolutionary limits in ecological traits drive Drosophila species distributions. Science 325: 1244-1246

Kingsolver JG, Huey RB (1998) Evolutionary analyses of morphological and physiological plasticity in thermally variable environments. Am Zool 38:545-560

Kirkpatrick M, Barton NH (1997) Evolution of a species' range. Am Nat 150:1-23

Knapp AK, Beier C, Briske DD, Classen AT and others (2008) Consequences of more extreme precipitation regimes for terrestrial ecosystems. Bioscience 58:811-821

Krebs RA, Feder ME, Lee J (1998) Heritability of expression of the $70 \mathrm{KD}$ heat-shock protein in Drosophila melanogaster and its relevance to the evolution of thermotolerance. Evolution 52:841-847

Kristensen TN, Barker JSF, Pedersen KS, Loeschcke V (2008a) Extreme temperatures increase the deleterious consequences of inbreeding under laboratory and seminatural conditions. Proc R Soc Lond B 275:2055-2061

Kristensen TN, Hoffmann AA, Overgaard J, Sørensen JG, Hallas R, Loeschcke V (2008b) Costs and benefits of cold acclimation in field-released Drosophila. Proc Natl Acad Sci USA 105:216-221

> Lande R, Shannon S (1996) The role of genetic variation in adaptation and population persistence in a changing environment. Evolution 50:434-437

Lawton JH (1999) Are there general laws in ecology? Oikos 84:177-192

le Roux PC, McGeoch MA (2008) Rapid range expansion and community reorganization in response to warming. Global Change Biol 14:2950-2962

Lenoir J, Gégout JC, Marquet PA, de Ruffray P, Brisse H (2008) A significant upward shift in plant species optimum elevation during the 20th century. Science 320:1768-1771

Levins R (1968) Evolution in changing environments: some theoretical explorations. Princeton University Press, Princeton, NJ

Lewontin RC (1974) The analysis of variance and the analysis of causes. Am J Hum Genet 26:400-411

Liao W, Reed DH (2009) Inbreeding-environment interactions increase extinction risk. Anim Conserv 12:54-61

> Liu Z, Gong P, Heckel DG, Wei W, Sun J, Li D (2009) Effects of larval host plants on over-wintering physiological dynamics and survival of the cotton bollworm, Helicoverpa armigera (Hübner) (Lepidoptera: Noctuidae). J Insect Physiol 55:1-9

Loeschcke V, Hoffmann AA (2007) Consequences of heat hardening on a field fitness component in Drosophila depend on environmental temperature. Am Nat 169: $175-183$

Lynch M (1996) A quantitative genetic perspective on conservation issues. In: Avise JC Hamrick JL (eds) Conservation genetics: case histories from nature. Chapman \& Hall, New York, p 457-501

> Mahlman JD (1998) Science and nonscience concerning human-caused global warming. Annu Rev Energy Environ 23:83-105

> Mangum CP, Hochachka PW (1998) New directions in comparative physiology and biochemistry: mechanisms, adaptations, and evolution. Physiol Zool 71:471-484

Marais E, Chown SL (2008) Beneficial acclimation and the 
Bogert effect. Ecol Lett 11:1027-1036

Mau-Crimmins TM, Schussman HR, Geiger EL (2006) Can the invaded range of a species be predicted sufficiently using only native-range data? Lehmann lovegrass (Eragrostis lehmanniana) in the southwestern United States. Ecol Model 193:736-746

Meehl GA, Stocker TF, Collins WD, Friedlingstein P and others (2007) Global climate projections. In: Solomon S, Qin D, Manning M, Chen Z and others (eds) Climate change 2007: the physical science basis. Contribution of Working Group I to the Fourth Assessment Report of the Intergovernmental Panel on Climate Change. Cambridge University Press, Cambridge, p 747-845

> Midgley GF, Hannah L, Millar D, Thuiller W, Booth A (2003) Developing regional and species-level assessments of climate change impacts on biodiversity in the Cape Floristic Region. Biol Conserv 112:87-97

Millien V, Lyons SK, Olson L, Smith FA, Wilson AB, Yom-Tov $\mathrm{Y}$ (2006) Ecotypic variation in the context of global climate change: revisiting the rules. Ecol Lett 9:853-869

> Mitchell WA, Angilletta MJ Jr (2009) Thermal games: frequency-dependent models of thermal adaptation. Funct Ecol 23:510-520

Mitchell K, Hoffmann AA (2010) Thermal ramping rate influences evolutionary potential and species differences for upper thermal limits in Drosophila. Funct Ecol 24:694-700

Møller AP, Flensted-Jensen E, Mardal W (2006) Rapidly advancing laying date in a seabird and the changing advantage of early reproduction. J Anim Ecol 75:657-665

Møller AP, Rubolini D, Lehikoinen E (2008) Populations of migratory bird species that did not show a phenological response to climate change are declining. Proc Natl Acad Sci USA 105:16195-16200

Nussey DH, Postma E, Gienapp P, Visser ME (2005) Selection on heritable phenotypic plasticity in a wild bird population. Science 310:304-306

- Overgaard J, Sørensen JG, Jensen LT, Loeschcke V, Kristensen TN (2010) Field tests reveal genetic variation for performance at low temperatures in Drosophila melanogaster. Funct Ecol 24:186-195

> Ozgul A, Tuljapurkar S, Benton TG, Benton TG, Pemberton JM, Clutton-Brock TH, Coulson T (2009) The dynamics of phenotypic change and the shrinking sheep of St. Kilda. Science 325:464-467

Parker BR, Vinebrooke RD, Schindler DW (2008) Recent climate extremes alter alpine lake ecosystems. Proc Natl Acad Sci USA 105:12927-12931

> Parmesan C (2006) Ecological and evolutionary responses to recent climate change. Annu Rev Ecol Evol Syst 37: 637-669

Parmesan C, Yohe G (2003) A globally coherent fingerprint of climate change impacts across natural systems. Nature 421:37-42

Parmesan C, Root TL, Willig MR (2000) Impacts of extreme weather and climate on terrestrial biota. Bull Am Meteorol Soc 81:443-450

> Pearson RG, Dawson TP (2003) Predicting the impacts of climate change on the distribution of species: Are bioclimate envelope models useful? Global Ecol Biogeogr 12:361-371

Pelini SL, Dzurisin JDK, Prior KM, Willams CM, Marsico TD, Sinclair BJ, Hellmann JJ (2009) Translocation experiments with butterflies reveal limits to enhancement of poleward populations under climate change. Proc Natl Acad Sci USA 106:11160-11165

Perry AL, Low PJ, Ellis JR, Reynolds JD (2005) Climate change and distribution shifts in marine fishes. Science 308:1912-1915
Pertoldi C, Bach LA (2007) Evolutionary aspects of climateinduced changes and the need for multidisciplinarity. J Therm Biol 32:118-124

> Pertoldi C, Bijlsma R, Loeschcke V (2007) Conservation genetics in a globally changing environment: present problems, paradoxes and future challenges. Biodivers Conserv 16:4147-4163

Pertoldi C, Bach LA, Loeschcke V (2008) On the brink between extinction and persistence. Biol Direct 3:47

Pertoldi C, Wójcik JM, Tokarska M, Kawałko A and others (2010) Genome variability in European and American bison detected using the BovineSNP50 BeadChip. Conserv Genet 11:627-634

Pigliucci M (2005) Evolution of phenotypic plasticity: Where are we going now? Trends Ecol Evol 20:481-486

$>$ Pörtner HO (2001) Climate change and temperaturedependent biogeography: oxygen limitation of thermal tolerance in animals. Naturwissenschaften 88:137-146

Pörtner HO (2002) Climate variations and the physiological basis of temperature dependent biogeography: systemic to molecular hierarchy of thermal tolerance in animals. Comp Biochem Physiol A 132:739-761

> Pörtner HO, Farrell AP (2008) Physiology and climate change. Science 322:690-692

> Pörtner HO, Knust R (2007) Climate change affects marine fishes through the oxygen limitation of thermal tolerance. Science 315:95-97

Prosser CL (1986) Adaptational biology. Molecules to organisms. John Wiley, New York

Rako L, Blacket MJ, McKechnie SW, Hoffmann AA (2007) Candidate genes and thermal phenotypes: identifying ecologically important genetic variation for thermotolerance in the Australian Drosophila melanogaster cline. Mol Ecol 16:2948-2957

Ranta E, Lundberg P, Kaitala V (2006) Ecology of populations. Cambridge University Press, Cambridge

Richardson DM, Hellmann JJ, McLachlan JS, Sax DF and others (2009) Multidimensional evaluation of managed relocation. Proc Natl Acad Sci USA 106:9721-9724

> Ricklefs RE (2008) Disintegration of the ecological community. Am Nat 172:741-750

Robinson MR, Wilson AJ, Pilkington JG, Clutton-Brock TH, Pemberton JM, Kruuk LEB (2009) The impact of environmental heterogeneity on genetic architecture in a wild population of Soay sheep. Genetics 181:1639-1648

> Scheiner SM (2002) Selection experiments and the study of phenotypic plasticity. J Evol Biol 15:889-898

> Schwager M, Johst K, Jeltsch F (2006) Does red noise increase or decrease extinction risk? Single extreme events versus series of unfavorable conditions. Am Nat 167:879-888

Schwenk K, Padilla DK, Bakken GS, Full RJ (2009) Grand challenges in organismal biology. Integr Comp Biol 49: $7-14$

Simberloff D (2004) Community ecology: Is it time to move on? Am Nat 163:787-799

> Simons AM, Johnston MO (1997) Developmental stability as a bet-hedging strategy. Oikos 80:401-406

Sinclair BJ (2001) Field ecology of freeze tolerance: interannual variation in cooling rates, freeze-thaw and thermal stress in the microhabitat of the alpine cockroach Celatoblatta quinquemaculata. Oikos 93:286-293

Smith JB, Schneider SM, Oppenheimer M, Yohe GW and others (2009) Assessing dangerous climate change through an update of the Intergovernmental Panel on Climate Change (IPCC) 'reasons' for concern. Proc Natl Acad Sci USA 106:4133-4137

Soberón J (2007) Grinnellian and Eltonian niches and geo- 
graphic distributions of species. Ecol Lett 10:1115-1123

Sørensen JG, Kristensen TN, Loeschcke V (2003) The evolutionary and ecological role of heat shock proteins. Ecol Lett 6:1025-1037

Sørensen JG, Nielsen MM, Loeschcke V (2007) Gene expression profile analysis of Drosophila melanogaster selected for resistance to environmental stressors. J Evol Biol 20: $1624-1636$

Steltzer H, Post E (2009) Seasons and life cycles. Science 324:886-887

Stenseth NC, Mysterud A, Ottersen G, Hurrell JW, Chan KS, Lima M (2002) Ecological effects of climate fluctuations. Science 297:1292-1296

Stillman JH (2003) Acclimation capacity underlies susceptibility to climate change. Science 301:65

Strauss SY, Lau JA, Carroll SP (2006) Evolutionary responses of natives to introduced species: What do introductions tell us about natural communities? Ecol Lett 9:357-374

Sutherst RW, Maywald GF, Bourne AS (2007) Including species interactions in risk assessments for global change. Global Change Biol 13:1843-1859

Teplitsky C, Mills JA, Alho JS, Yarrall JW, Merilä J (2008) Bergmann's rule and climate change revisited: disentangling environmental and genetic responses in a wild bird population. Proc Natl Acad Sci USA 105:13492-13496

Terblanche JS, Deere JA, Clusella Trullas S, Janion C, Chown SL (2007) Critical thermal limits depend on methodological context. Proc R Soc Lond B 274:2935-2942

Thomas CD, Cameron A, Green RE, Bakkenes M and others (2004) Extinction risk from climate change. Nature 427: $145-148$

Thuiller W, Lavorel S, Sykes MT, Araújo MB (2006) Using niche-based modelling to assess the impact of climate change on tree functional diversity in Europe. Divers Distrib 12:49-60

Tolley KA, Davies SJ, Chown SL (2008) Deconstructing a controversial local range expansion: conservation biogeography of the painted reed frog (Hyperolius marmoratus) in South Africa. Divers Distrib 14:400-411

Trenberth KE, Shea DJ (2005) Relationships between precipitation and surface temperature. Geophys Res Lett 32: L14703. doi:10.1029/2005GL022760

Trenberth KE, Jones PD, Ambenje P, Bojariu R and others (2007) Observations: surface and atmospheric climate change. In: Solomon S, Qin D, Manning M, Chen Z and others (eds) Climate change 2007: the physical science basis. Contribution of Working Group I to the Fourth Assessment Report of the Intergovernmental Panel on Climate Change. Cambridge University Press, Cambridge, p 235-336

Tuljapurkar S, Horvitz CC, Pascarella JB (2003) The many growth rates and elasticities of populations in random environments. Am Nat 162:489-502

Tylianakis JM, Didham RK, Bascompte J, Wardle DA (2008) Global change and species interactions in terrestrial ecosystems. Ecol Lett 11:1351-1363

- Umina PA, Weeks AR, Kearney MR, McKechnie SW, Hoffmann AA (2005) A rapid shift in a classic clinal pattern in Drosophila reflecting climate change. Science 308: 691-693

van Asch M, van Tienderen PH, Holleman LJM, Visser ME (2007) Predicting adaptation of phenology in response to climate change, an insect herbivore example. Global Change Biol 13:1596-1604

van Buskirk J, Steiner UK (2009) The fitness costs of developmental canalization and plasticity. J Evol Biol 22:852-860

Van Doorslaer W, Stoks R, Duvivier C, Bednarska A, De Meester L (2009) Population dynamics determine genetic adaptation to temperature in Daphnia. Evolution 63: $1867-1878$

Vannier G (1994) The thermobiological limits of some freezing tolerant insects: the supercooling and thermostupor points. Acta Oecol 15:31-42

Vera JC, Wheat CW, Fescemyer HW, Frilander MJ, Crawford DL, Hanski I, Marden JH (2008) Rapid transcriptome characterization for a nonmodel organism using 454 pyrosequencing. Mol Ecol 17:1636-1647

- Walther GR, Post E, Convey P, Menzel A and others (2002) Ecological responses to recent climate change. Nature 416:389-395

Walther GR, Roques A, Hulme PE, Sykes MT and others (2009) Alien species in a warmer world: risks and opportunities. Trends Ecol Evol 24:686-693

Wang Z, Brown JH, Tang Z, Fang J (2009) Temperature dependence, spatial scale, and tree species diversity in eastern Asia and North America. Proc Natl Acad Sci USA 106:13388-13392

Wegner KM, Kalbe M, Milinski M, Reusch TBH (2008) Mortality selection during the 2003 European heat wave in three-spined sticklebacks: effects of parasites and MHC genotype. Evol Biol 8:124

Welbergen JA, Klose SM, Markus N, Eby P (2008) Climate change and the effects of temperature extremes on Australian flying foxes. Proc R Soc Lond B 275:419-425

Werner EE, Relyea RA, Yurewicz KL, Skelly DK, Davis CJ (2009) Comparative landscape dynamics of two anuran species: climate-driven interaction of local and regional processes. Ecol Monogr 79:503-521

Wiens JJ, Graham CH (2005) Niche conservatism: integrating evolution, ecology, and conservation biology. Annu Rev Ecol Evol Syst 36:519-539

Willi Y, Hoffmann AA (2009) Demographic factors and genetic variation influence population persistence under environmental change. J Evol Biol 22:124-133

Zhou L, Dai A, Dai Y, Vose RS, Zou CZ, Tian Y, Chen H (2009) Spatial dependence of diurnal temperature range trends on precipitation from 1950 to 2004. Clim Dyn 32:429-440

Zurell D, Jeltsch F, Dormann C, Schröder B (2009) Static species distribution models in dynamically changing systems: How good can predictions really be? Ecography 32:733-744

Proofs received from author(s): July 21, 2010 